\title{
Dependence of Cost of Housing on Transport Accessibility of Area: Case of City of Irkutsk
}

\author{
Maksim Sharov \\ Transport Department \\ Irkutsk National Research Technical University \\ Irkutsk, Russia \\ sharov.maksim@gmail.com
}

\author{
Alexsandra Butuzova \\ Transport Department \\ Irkutsk National Research Technical University \\ Irkutsk, Russia \\ alexa.kupriyanova@gmail.com
}

\author{
Alla Litkina \\ Transport Department \\ Irkutsk National Research Technical University \\ Irkutsk, Russia \\ allalytkina38@gmail.com
}

\begin{abstract}
The issues of the estimation of transport accessibility of the area, as well as influence of transport accessibility on per housing square meter price, are considered in the article.

In particular, the dependence of the possible per square meter price on the value of transport accessibility has been defined.
\end{abstract}

Keywords-urban planning, transport accessibility, Cost of Housing

\section{INTRODUCTION}

The concept of sustainable development and comfortable city environment presuppose the priority-oriented development of public transit transport systems and "green" mobility (i.e. non-mechanized movements).

Priority-oriented development of public transit transport systems is ensured by either technical solutions or urban planning. Modern foreign urban planning theory and practice include the following most common urban planning solutions to ensure the priority-oriented development of public transit transport systems:

- mixed-use development to reduce the need for longdistance travel;

- development of areas, oriented to public transit transport (transit oriented development), consider the formation of an attractive and comfortable environment that includes the infrastructure of public transit transport;

- $\quad$ increase in the intensity of use of areas adjacent to the corridors of public transit transport.

The attractiveness of the areas increases due to the improvement of the accessibility of public transit transport, consequently, the concentration of institutions in the service sector and places of employment grows.

\section{ASSESSMENT OF TRANSPORT ACCESSIBILITY OF THE TERRITORY}

In the world practice of urban planning, the accessibility of an area is determined by the following factors: transport accessibility of the area; availability of all necessary services; presence of a sufficient number of public spaces.

In construction, transport accessibility is a normative indicator of the time consumption on the transportation between different points within the systems of group accommodation [1]. In the process of designing city streets and roads, one of the key parameters to determine the quality of the city's road network is the time of transportation between any two points of the city [2].

If one considers this issue from the point of view of transport, the accessibility is a total time consumption required for the travelling on any purpose (travel to and from place of employment, on cultural and domestic purposes and so on).

Transport supportability of a city and regional areas is applied as one of the economic characteristics.

Improving transport accessibility is an important mechanism to implement regional policies. The efficient implementation of this mechanism makes it possible to reduce disproportions in the territorial development of various parts of a city and the country as a whole, and to increase the attractiveness of remote and sparsely populated areas.

In this regard, it is necessary to specify the need to develop modern criteria and standards for estimation of the transport accessibility of the territory. In the Russian Federation, since the Soviet era, the building codes and regulations, standard (SNiP 2.07.01-89), have been in operation to set the requirements for the time consumption on labor travelling (Table 1). Even in cities with a million-plus population, $90 \%$ of working people should not spend more than 45 minutes on travelling from the place of their residence to the place of employment (one way). 
TABLE I. TIME CONSUMPTION ON TRAVELLING FROM THE PLACE OF THE RESIDENCE TO THE PLACE OF EMPLOYMENT

\begin{tabular}{|c|c|}
\hline $\begin{array}{c}\text { City population, thousand } \\
\text { people }\end{array}$ & Time consumption, min \\
\hline 2000 & 45 \\
\hline 1000 & 40 \\
\hline 500 & 37 \\
\hline 250 & 35 \\
\hline 100 & 30 \\
\hline
\end{tabular}

The specified time consumption rates should be interpolated to receive intermediate values of the estimated urban population. In addition, the standard states that, for:

- those who travel daily to a place of employment, located in the city center, from other settlements: it is allowed to increase specified norms of time consumption, but not more than twice;

- residents of rural settlements, the time consumption on labor travelling (pedestrian or using transport) within the agricultural enterprise, as a rule, should not exceed 30 minutes.

The special group includes cities with a population of more than 2 million people. The maximum allowable time consumption should be determined by special justifications, taking into account the actual resettlement, location of places of employment and the level of development of transport systems.

The results of the questionnaire survey carried out by the IRNITU Transport Laboratory in Irkutsk showed [6-9] that even the existing town planning standard of 38 minutes per one travel is realized only by $50 \%$. In general, the results of the estimation of the enlarged zones of the city of Irkutsk are presented in Figure 1.

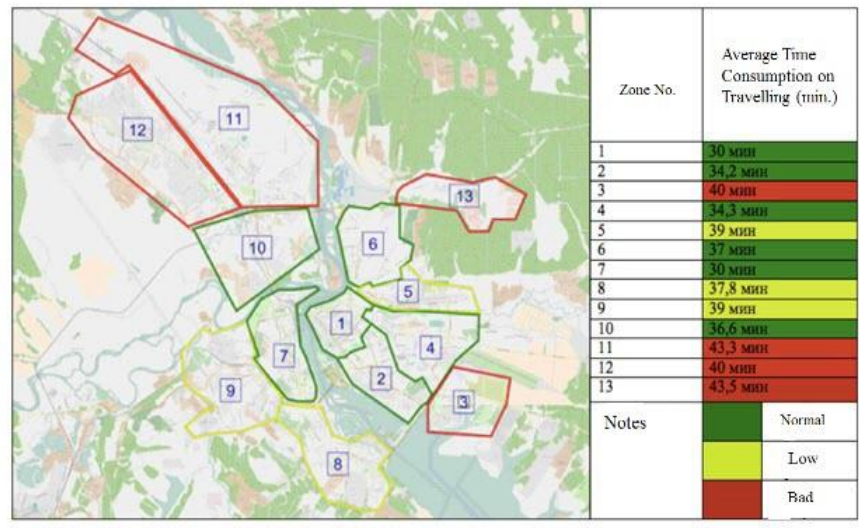

Fig.1. Average time consumption on one-way labor travelling in the city of Irkutsk

The possibility to estimate the impact of transport accessibility on per one housing square meter price is provided by the availability of such information. There is hardly any other appropriate way to define the real impact of the price, since this very parameter of the formation of the price of an apartment or office space is one of the most significant.
Having analyzed the housing market of the city of Irkutsk, the average per one square meter price in newly built houses and at the pre-owned market is defined (Figure 2).

The system to estimate the impact of transport accessibility of a building (residential, business, shopping and entertainment) on its market value includes a number of parameters:

- $\quad$ remoteness from the central part of the city;

- proximity of highways;

- $\quad$ proximity of metro stations or ground transportation stops (in the case of the city of Irkutsk, the proximity of metro stations is not an estimation parameter);

- availability of parking lots, car parks or garage cooperative

- developed system of access roads (construction of new ones, reconstruction of old ones);

- $\quad$ proximity of points of daily attraction (kindergartens, schools, medical centers, supermarkets, etc.);

- $\quad$ impact of noise, vibration and exhaust gases [3]

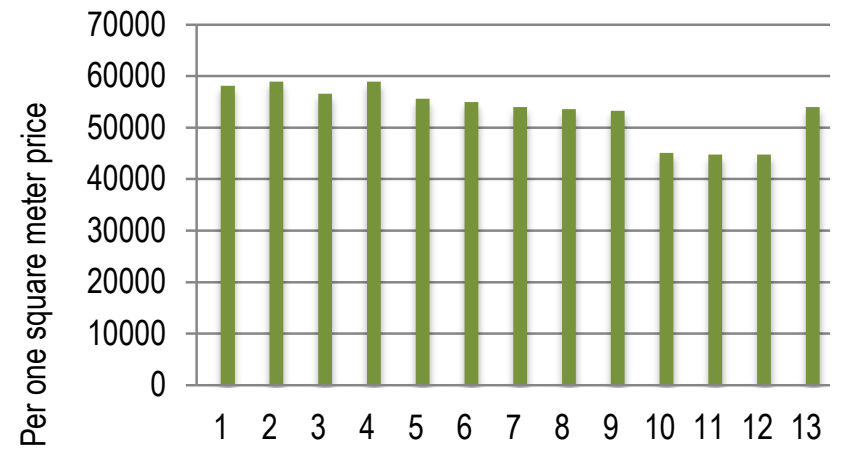

Transport zone number

Fig. 2. Average price per one square meter according to transport zones in Irkutsk

The most research works focus on estimation of the distance from the city center, since the main social objects are located there.

In all countries, the level of transport accessibility is measured by the time required to travel from a specific point of the city to the outer limits of the central district. Ranking availability makes it possible to create an informed zoning of the city's territory.

As the level of transport access decreases, the cost of travel to the central part of the city increases, and per square meter price will gradually decrease.

The analysis showed that residential buildings located in 1 , 2, 4, 6, 7, 8 and 10 zones will have the highest level of comfort in terms of transport accessibility, residential buildings located in 3, 5, 9, 11,12 and13 zones (Figure 3 ) - the least one. Accordingly, the location of the object will determine their cost.

However, it should be noted that, despite the fact that the transport accessibility is low in the third transport zone, per one square meter price amounts to RUB 56533.82 ; it is explained by the fact that the building is mostly elite, and 
people living in the area use individual means of transportation.

Based on the analysis of the average market per one square meter price in a newly-built and pre-owned residential fund, it can be concluded that residential buildings located in the central part of the city are the most attractive.

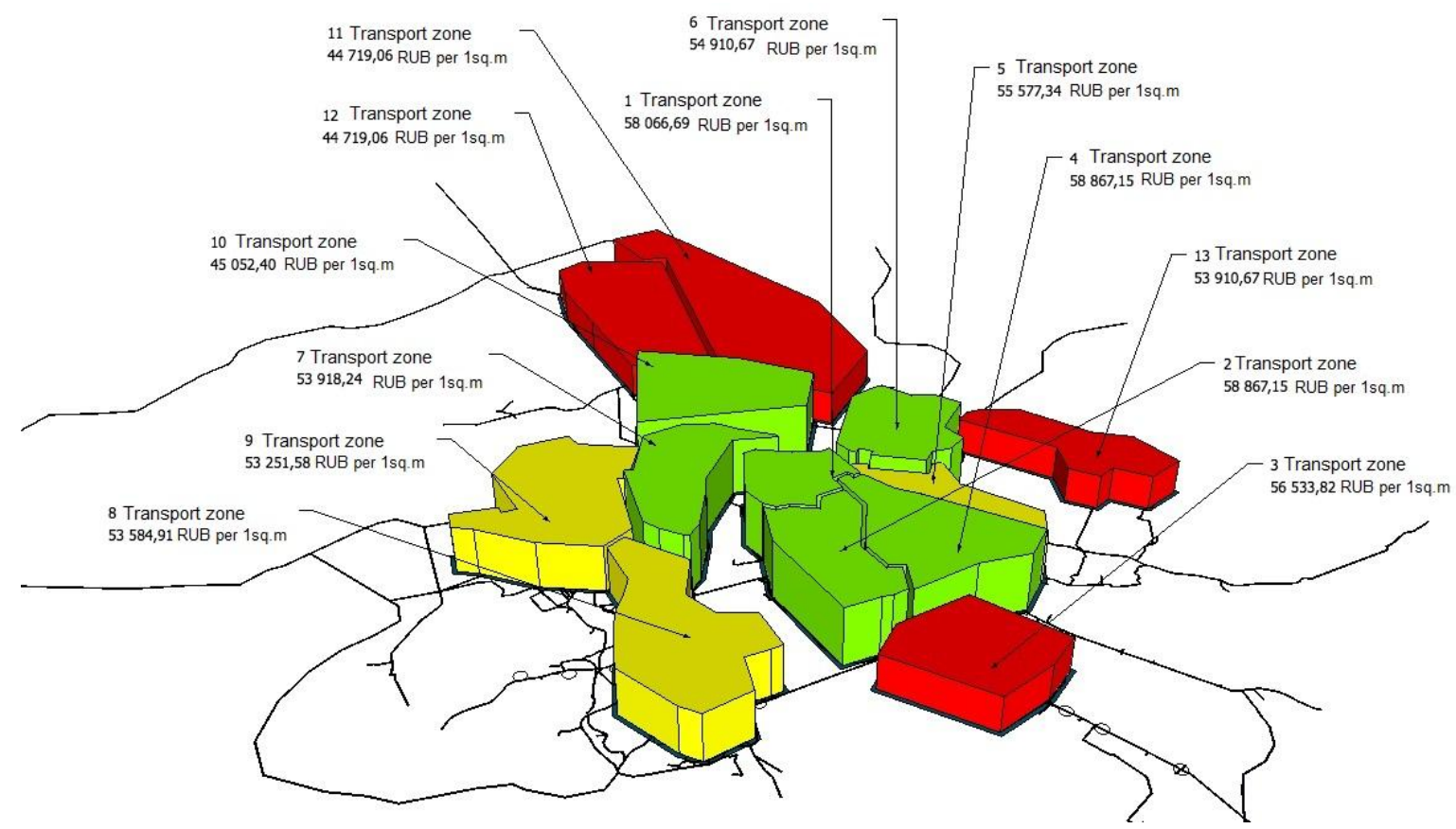

Let us note:

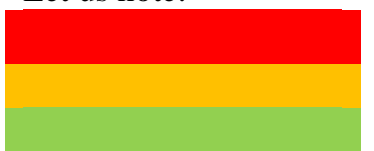

Satisfactory accessibility

Average accessibility

High accessibility

Fig. 3. Per square meter price according to transport zones in Irkutsk

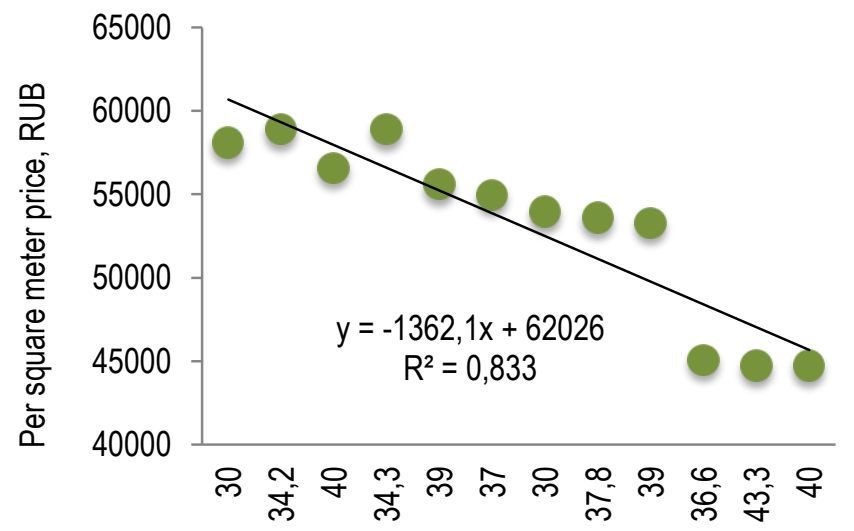

Time consumption on travelling, mir

Fig. 4. Dependence of the per square meter price on the time consumption on travelling

\section{CONCLUSIONS}

Based on the analysis, the time consumption on travelling and the per square meter price of residential real estate in the city of Irkutsk was determined. For a functional explanation of the dependence of the per square meter price on the time consumption on travelling for labor purposes, a trend line was drawn up and the equation of this line was defined. (Figure 4).

The farther from the geographical center of the city a residential building is, the lower the level of transport accessibility of the area is, and as a result, the price of one square meter falls.

Going beyond the boundaries of the geometric center reduces the value of the real estate. However, the value of the object increases due to the benefits of location (transport nodes, objects of social attraction) and causes an increase in its price.

Finally, we can conclude that, in general, increasing level of transport accessibility of the area is one of the key factors of economic growth in our country. The availability of tools to conduct a detailed and accurate estimation of accessibility is currently one of the most important scientific studies conducted in the framework of transport and urban planning. 


\section{References}

1. Yu. Lanzberg, Yu. Stavnichy, A guide to designing city streets and roads, Moscow: Stroiizdat, 1980, p.324.

2. E. Palagin, Terminological dictionary on construction in 12 languages, Moscow: Russian language, 1986, P. 861.

3. D. Friedman, N. Ordway, Analysis and evaluation of income-producing real estate, Moscow: Delo, 1997, p. 460.

4. SNIP 2.07.01-89*. Urban planning. Planning and development of urban and rural settlements. Gosstroy USSR. Moscow: TsNTP Gosstroy USSR, 1994

5. V. Dubovik, "Methods for estimation transport accessibility of the area," Regional studies, No. 4 (42), 2013.

6. A. Mikhailov, A. Levashev, M. Sharov, "Modern methods of assessing the quality of road traffic management in cities," Irkutsk, pp. 2015-218, No. 64-B2015.

7. M. Sharov, A. Levashev, A. Mikhailov, The Irkutsk transportation master plan solutions for public transport system development. WIT Transactions on Ecology and the Environment, 190, vol. 1, 2014, pp. 651-660. doi:10.2495/EQ140621.

8. M. Sharov, A. Mikhailov, "Urban transport system reliability indicators," Paper presented at the Transportation Research Procedia, 20, 2017, pp. 591-595. doi:10.1016/j.trpro.2017.01.095

9. A. Fedotov, N. Kuznetsov, A. Lysenko, V. Vlasov, "Car suspension system monitoring under road conditions," Paper presented at the AIP Conference Proceedings, 2017. 1915 doi:10.1063/1.5017362.

10. A.Mikhailov, M. Sharov, "On the development of a modern system of criteria for assessing the quality of public passenger transport," Izvestiya Volgograd State Technical University. Series: Land transport systems, vol. 9, No. 19 (146), 2014, pp. 64-66.

11. RG. Mugion, M.Toni, H. Raharjo, L. Di Pietro, SP Sebathu, "Does the service quality of urban public transport enhance sustainable mobility?'
JOURNAL OF CLEANER PRODUCTION pp. 1566 - 1587, 10.1016/j.jclepro.2017.11.052

FEB 102018 t. 174

. Mlynarski, Stanislaw; Pilch, Robert; Smolnik, Maksymilian, "Methodology of network systems reliability assessment on the example of urban transport. Eksploatacja i niezawodnosc-maintenance and reliability," t: 20, n: 2, 2018, pp. 278-283.

13. Van Lierop, Dea; Badami, Madhav G.; El-Geneidy, Ahmed M. "What influences satisfaction and loyalty in public transport? A review of the literature." TRANSPORT REVIEWS. t: 38 n: 1, 2018, pp. 52-72.

14. Nesheli, Mahmood Mahmoodi; Ceder, Avishai (Avi); Brissaud, Robin, "Public transport service-quality elements based on real-time operational tactics," TRANSPORTATION, t: 44 n: 5, pp. 957-975.

15. Fu, Xuemei; Juan, Zhicai, "Understanding public transit use behavior: integration of the theory of planned behavior and the customer satisfaction theory," TRANSPORTATION, t: 44 n: 5, 2017, pp. 10211042

16. E.Podoskina, Y. Mihaylyukova, "Transport accessibility as a factor of investment attractiveness of the suburban real estate." Scientific Almanac, No. 1-1 (15), 2016, pp. 218-222.

17. E. Kovaleva, "Integral transport accessibility as an indicator of the quality of transport services," Journal of the University of Water Communications, No.3, 2011, pp. 171-175.

18. V.Gudkov, N.Dulina, V.Tokarev, "Transport accessibility of a modern large city. Freight and passenger motor transport,“"No. 4. 2009, p. 29 33.

19. P. Sapanov, "Modern transport accessibility of Moscow districts and approaches to its evaluation." Geodesy and cartography, No.12, 2015, pp. 15-21.

20. S. Yatsenko, S. Kolganov, "Marketing research of demand in the market of passenger transport services in Irkutsk." Bulletin of Irkutsk State Technical University, No. 5 (64), 2012, pp. 122-128. 